\title{
Rainfall Effect on Dissipation and Movement of DiURon and SimAZINE IN A VINEYARD SOIL ${ }^{1}$
}

\author{
Efeito da Chuva na Dissipação e Movimentação de Diuron e Simazine em Solo de Vinha
}

\author{
ALISTER, C. ${ }^{2}$ and KOGAN, M. ${ }^{2}$
}

\begin{abstract}
From 2003 to 2007, a field study was performed in a vineyard in Chile to investigate diuron and simazine soil behavior and the effect of additional rainfall. Both herbicides were applied once a year at a rate of $2.0 \mathrm{~kg} \mathrm{ha}^{-1}$ a.i. Herbicide concentrations in soil were measured at $0,10,20,40,90$ and 340 days after application, under two pluviometric conditions, natural rainfall and natural rainfall plus irrigation with $180 \mathrm{~mm}$ of simulated rainfall during the first 90 days after application. Soil partition coefficient $\left(\mathrm{K}_{\mathrm{d}}\right)$ varied in the soil profile ( 0 to $90 \mathrm{~cm}$ deep) from 6.75 to $2.04 \mathrm{~mL} \mathrm{~g}^{-1}$ and from 1.4 to $0.66 \mathrm{~mL} \mathrm{~g}^{-1}$ and the maximum soil adsorption capacity was approximately $18.3 \mathrm{mg} \mathrm{g}^{-1}$ and $8.3 \mathrm{mg} \mathrm{g}^{-1}$ for diuron and simazine, respectively. Diuron and simazine reached up to 90 and $120 \mathrm{~cm}$ of soil depth, with an average of $8.3 \%$ and $62.4 \%$ of herbicide moved below $15 \mathrm{~cm}$ in the soil, respectively. Simazine soil half-life $\left(\mathrm{DT}_{50}\right)$ was 38.1 days and 7.5 days, whereas the half life for diuron varied from 68.0 and 24.6 for natural rainfall and irrigated, respectively. The average of residual simazine remaining in the whole soil profile after 90 DAA was $25.4 \%$ and $39.9 \%$ for diuron, with no effect of additional rainfall amount. At 340 DAA the amount of simazine in the whole soil profile corresponded to $13.2 \%$ of the initial amount applied, being diuron more persistent with $21.5 \%$ of the initial herbicide applied. The high movement in soil of both herbicides could be due to a non-equilibrium sorption process explained by preferential flow, low $\mathrm{K}_{\mathrm{d}}$ and high desorption.
\end{abstract}

Keywords: agrochemicals, $K_{\mathrm{oc}}, K_{\mathrm{d}}$, desorption, leaching.

RESUMO - Entre 2003 e 2007, foi conduzido um estudo de campo em uma vinha no Chile para investigar o comportamento de diuron e simazine no solo e o efeito de irrigação extra. Ambos os herbicidas foram aplicados uma vez por ano, numa base de $2.0 \mathrm{~kg} \mathrm{ha}^{-1}$ a.i. Foram medidas as concentrações de herbicida no solo após 0, 10,20,40, 90 e 340 dias da aplicação, sob duas condições pluviométricas distintas, chuvas naturais e chuvas naturais mais irrigação com $180 \mathrm{~mm}$ de chuva artificial durante os primeiros 90 dias após a aplicação. O coeficiente de partição no solo $\left(\mathrm{K}_{d}\right)$ no perfil de solo (a uma profundidade de 0 a $90 \mathrm{~cm}$ ) foi de $2.04 \mathrm{~mL} \mathrm{~g}^{-1}$ e de 1, 4 a 0 , $66 \mathrm{~mL} \mathrm{~g}^{-1}$, e a capacidade de adsorção máxima do solo foi de aproximadamente 18,3 $\mathrm{mg} \mathrm{g}^{-1}$ e $8.3 \mathrm{mg} \mathrm{g}^{-1}$ para diuron e simazine respectivamente. O diuron e o simazine atingiram uma profundidade de até $90 \mathrm{e}$ $120 \mathrm{~cm}$ no solo, com uma média de, respectivamente, 8,3\% e 62,4\% de movimentação do herbicida abaixo de $15 \mathrm{~cm}$ do solo. A meia-vida de simazine no solo (DT ${ }_{50}$ ) foi de 38,1 dias e 7,5 dias, enquanto a meia-vida para o diuron foi de 68,0 e 24, 6, com chuva natural e irrigação respectivamente. A média de simazine residual remanescente em todo o perfil do solo após 90 DAA foi de 25,4\%, e de 39,9\% para o diuron, sem nenhum efeito de quantidade de chuva adicional. Em 340 DAA, a quantidade de simazine presente em todo o perfil do solo correspondeu a 13,2\% da quantidade inicial aplicada, sendo o diuron mais persistente, com 21,5\% do herbicida inicial aplicado. Pode-se atribuir a elevada movimentação no solo com ambos os herbicidas a um processo de não-equilíbrio de sorção, explicado por fluxo preferencial, baixo $\mathrm{K}_{d}$ e elevada dessorção.

Palavras-chave: agrotóxicos, $K_{\mathrm{oc}}, K_{\mathrm{d}}$ dessorção, lixiviação.

1 Recebido para publicação em 5.8.2010 e na forma revisada em 17.12.2010.

2 Escuela de Ciencias Agrícolas, Universidad de Viña del Mar, Avenida Agua Santa 7055, Viña del Mar, Chile. Tel: (+56) 32 2462415, <calister@uvm.cl; mkogan@uvm.cl>. 


\section{INTRODUCTION}

Simazine and diuron are important soilactive herbicides used in fruit production in Chile. However, there are problems related to water contamination and mainly in groundwater, with the use of pesticides in several countries in Europe and in North America (Troiano et al., 1994; Lennartz et al., 1997; Wade et al., 1998; Jacobsen et al., 1999; Field et al., 2003; NAWQA, 2003; Spalding et al., 2003). For this reason most of the Chilean fruit and wine producers restrict the use of simazine as a response to this issue and to satisfy their commercial partners.

The knowledge about simazine and diuron soil dynamics has changed over time. In the past, both herbicides were classified as not readily leachable and with risk of soil accumulation. Different reports have indicated highly variable mobility in soil and leaching risk under different soil and climatic conditions (Dawson et al., 1968; Heeney et al., 1981; Barreda et al., 1996; Itoh \& Manabe, 1997; Patzold \& Brummer, 1997; Tworkoski, et al., 2000; Rouchaud et al., 2000; Alister et al., 2005; Matallo et al., 2005; Landry et al., 2006).

Diuron can present soil sorption coefficient $\left(\mathrm{K}_{\mathrm{d}}\right)$ values, between 2.9 to $75 \mathrm{~mL} \mathrm{~g}^{-1}$ (ARS, 2001; Liyanage et al., 2006), in comparison to simazine, which can present lower $\mathrm{K}_{\mathrm{d}}$ values, between 0.48 to $13.9 \mathrm{~mL} \mathrm{~g}^{-1}$ (Kookana et al., 1992; ARS, 2001; Wauchope et al., 1992). Halflives reported for both herbicides are quite different, 30 to 365 and 19 to 186 days, for diuron and simazine, respectively (Wauchope et al., 1992; Flury, 1996; Rouchaud et al., 2000; ARS, 2001; Gooddy et al., 2002). According to these diuron properties, one could expect that diuron would be less leachable than simazine. But in the field, degradation and movement in soil are quite different from the expected behavior (Gooddy et al., 2002; Alister et al., 2005). Nevertheless, estimations of relative environmental risk for both herbicides, using some relative indexes, in relation to soil leaching and water contamination, such asEnvironmental Risk Index-ERI loading $_{\text {(Alister }}$ \& Kogan, 2006), Leaching Potential Index-LPI (Meeks \& Dean, 1990), Groundwater Ubiquity Score-GUS (Gustafson, 1989) and Leaching Index-LEACH (Laskowski et al., 1982), indicate that simazine and diuron do not show appreciable differences.

The uncertainty of the herbicide behavior under particular soil and climatic conditions in Chilean vineyards and the lack of local data related to the environmental pesticide dynamics make it very difficult to develop adequate pesticide management and regulatory practice guidelines to diminish the potential risk of contamination of surface and groundwater resources.

Based on the simazine behavior in the soil at a vineyard in the Casablanca Valley during the 2003 season (Alister et al., 2005), we continued with the research project for another three years to compare the soil dynamics of diuron and simazine by studying: a) the dissipation and soil mobility of diuron and simazine over three seasons, b) the effect of extra rainfall on these processes, and c) sorption and desorption of both herbicides and their relation to soil properties.

\section{MATERIAL AND METHODS}

\section{Study conditions and herbicide treatments}

From August 2003 to August 2007, in a commercial vineyard located in the Casablanca Valley (Latitude $33^{\circ} 16^{\prime} \mathrm{S}$ and Longitude $71^{\circ} 23^{\prime} \mathrm{W}$ ) in Chile, diuron and simazine were applied at a rate of $2 \mathrm{~kg} \mathrm{ha}^{-1}$ a.i. to bare soil in an experimental area $(1.4 \mathrm{ha})$ in August of each year, using a backpack sprayer calibrated to deliver $200 \mathrm{~L} \mathrm{ha}^{-1}$ at $0.35 \mathrm{mPa}$.

This area was characterized according to selected soil properties (Table 1) and four homogeneous zones were identified using cluster analysis. In each homogeneous zone all vegetation was removed from two $3 \mathrm{~m}^{2}$ sections in between the rows of grape plants to avoid foliage interference with the applied herbicide. One section of each zone received natural rainfall (Figure 1), and the other section was augmented with simulated rainfall using a PVC (75 $\mathrm{mm}$ diameter) perforated pipe delivering $30 \mathrm{~mm}$ of water every 15 days over 90 days after the herbicide application (DAA) each year (irrigated). Average temperatures for the air and at $15 \mathrm{~cm}$ of soil depth are shown in Figure 2. 
Table 1 - Physicochemical properties of the soil

\begin{tabular}{|c|c|c|c|c|c|c|c|}
\hline Soil depth & Density & $\mathrm{nH}$ & $\mathrm{CIC}$ & $\mathrm{OC}$ & Sand & Silt & Clay \\
\hline$(\mathrm{cm})$ & $\left(\mathrm{g} \mathrm{cm}^{-3}\right)$ & & $\left(\right.$ meq $\left.100 \mathrm{~g}^{-1}\right)$ & \multicolumn{4}{|c|}{$(\%)$} \\
\hline $0-15$ & $\begin{array}{c}1.56 \\
( \pm 0.16) \\
\end{array}$ & $\begin{array}{c}6.10 \\
( \pm 0.20) \\
\end{array}$ & $\begin{array}{r}14.88 \\
( \pm 2.80) \\
\end{array}$ & $\begin{array}{c}1.28 \\
( \pm 0.27) \\
\end{array}$ & $\begin{array}{c}44.01 \\
( \pm 6.48) \\
\end{array}$ & $\begin{array}{c}35.20 \\
( \pm 4.48) \\
\end{array}$ & $\begin{array}{r}20.79 \\
( \pm 2.37) \\
\end{array}$ \\
\hline $15-30$ & $\begin{array}{c}1.40 \\
( \pm 0.04) \\
\end{array}$ & $\begin{array}{c}6.05 \\
( \pm 0.15) \\
\end{array}$ & $\begin{array}{c}14.64 \\
( \pm 2.49) \\
\end{array}$ & $\begin{array}{c}0.63 \\
( \pm 0.17) \\
\end{array}$ & $\begin{array}{c}41.88 \\
( \pm 7.28) \\
\end{array}$ & $\begin{array}{c}34.26 \\
( \pm 5.61) \\
\end{array}$ & $\begin{array}{c}23.86 \\
( \pm 2.94) \\
\end{array}$ \\
\hline $30-60$ & $\begin{array}{c}1.37 \\
( \pm 0.16)\end{array}$ & $\begin{array}{c}6.30 \\
( \pm 0.14)\end{array}$ & $\begin{array}{c}11.63 \\
( \pm 0.33)\end{array}$ & $\begin{array}{c}0.50 \\
( \pm 0.09)\end{array}$ & $\begin{array}{c}47.38 \\
( \pm 5.10)\end{array}$ & $\begin{array}{c}29.94 \\
( \pm 2.55)\end{array}$ & $\begin{array}{r}22.68 \\
( \pm 3.52) \\
\end{array}$ \\
\hline $60-90$ & $\begin{array}{c}1.45 \\
( \pm 0.03)\end{array}$ & $\begin{array}{c}6.61 \\
( \pm 0.16)\end{array}$ & $\begin{array}{c}11.80 \\
( \pm 0.52)\end{array}$ & $\begin{array}{c}0.31 \\
( \pm 0.05)\end{array}$ & $\begin{array}{c}51.34 \\
( \pm 7.46)\end{array}$ & $\begin{array}{c}23.50 \\
( \pm 4.40)\end{array}$ & $\begin{array}{c}25.16 \\
( \pm 4.93)\end{array}$ \\
\hline
\end{tabular}

Values are means of 20 samples \pm standard deviation.

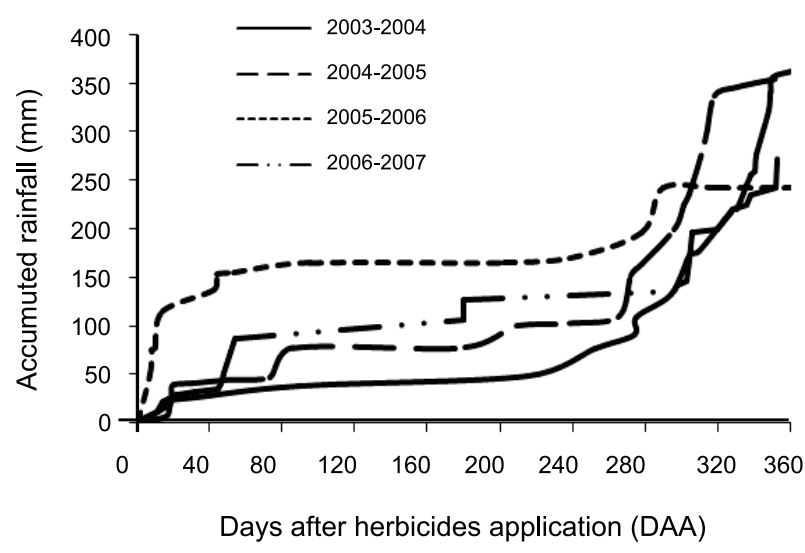

Figure 1- Accumulated natural rainfall from August 2002 to August 2007.

\section{Soil samples for herbicide analysis}

Soil samples were collected utilizing a steel soil sampler (0.06 $\mathrm{m}$ diameter), avoiding contaminating deeper soil with surface soil, from $0-15$ and $15-30 \mathrm{~cm}$ at $0,10,20$ and 40 days after herbicide application (DAA), and $0-15,15-30,30-60$ and $60-90 \mathrm{~cm}$ at 90 and 340 DAA. In 2005 and 2006, samples from 90 to $120 \mathrm{~cm}$ depth were also taken. Each soil sample was packed in a plastic bag, kept in a cooler at $4{ }^{\circ} \mathrm{C}$, carried to the laboratory and frozen at $-18{ }^{\circ} \mathrm{C}$ until analysis.

Herbicides were extracted from $20 \mathrm{~g}$ soil sample for each herbicide and shaken at $300 \mathrm{rpm}$ for $90 \mathrm{~min}$ with $40 \mathrm{~mL}$ of methanol. The extracts were filtered and concentrated to dryness in a rotary evaporator and resuspended in $1 \mathrm{~mL}$ methanol, and transferred to $1.5 \mathrm{~mL}$ glass vial and analyzed using highpressure liquid chromatography with a diodearray detector (HPLC-DAD). The HPLC unit was equipped with a Lichrospher ${ }^{\circledR} 100 \mathrm{RP}-185 \mu \mathrm{m}$ Hibar ${ }^{\circledR}$ Pre-Packed RT 125-4 column. The liquid phase used was acetonitrile and ammonium acetate $10 \mathrm{mmol}$. The acetonitrile gradient was: 0 at $10 \min 30 \% ; 10-11 \mathrm{~min} 70 \%$; and $11-13 \mathrm{~min} 30 \%$. The column temperature was $25^{\circ} \mathrm{C}$ and the flow rate was $1 \mathrm{~mL} \mathrm{~min}{ }^{-1}$. The injection volume was $30 \mu \mathrm{L}$. The detector (Hitachi model Elite LaChrom L-2450) was set at $220 \mathrm{~nm}$ and $250 \mathrm{~nm}$ for simazine and diuron, respectively.

Herbicide recovery from spiked soil was $93 \pm 6 \%$ and $99 \pm 5 \%$ for simazine and diuron, respectively. Detection limits were $3 \mu \mathrm{g} \mathrm{L}^{-1}$ and $9 \mu \mathrm{g} \mathrm{L}^{-1}$ for simazine and diuron, respectively. For each soil sample series analyzed, laboratory blank, spiked and untreated soil samples were included.

\section{Determination of sorption and desorption coefficients}

Six milliliters of aqueous $0.01 \mathrm{M} \mathrm{CaCl}_{2}$ solutions of diuron and simazine, at six concentrations depending on their water solubility, were added to $3 \mathrm{~g}$ of air-dried soil. These soil suspensions were shaken endover-end for $8 \mathrm{~h}$ at $200 \mathrm{rpm}$ at room temperature and then centrifuged for $20 \mathrm{~min}$ at $3110 \mathrm{~g}$. One milliliter of each supernatant solution was filtered through a $0.45 \mu \mathrm{m}$ fiberglass filter and directly quantified using HPLC-DAD as before. The amount of diuron 

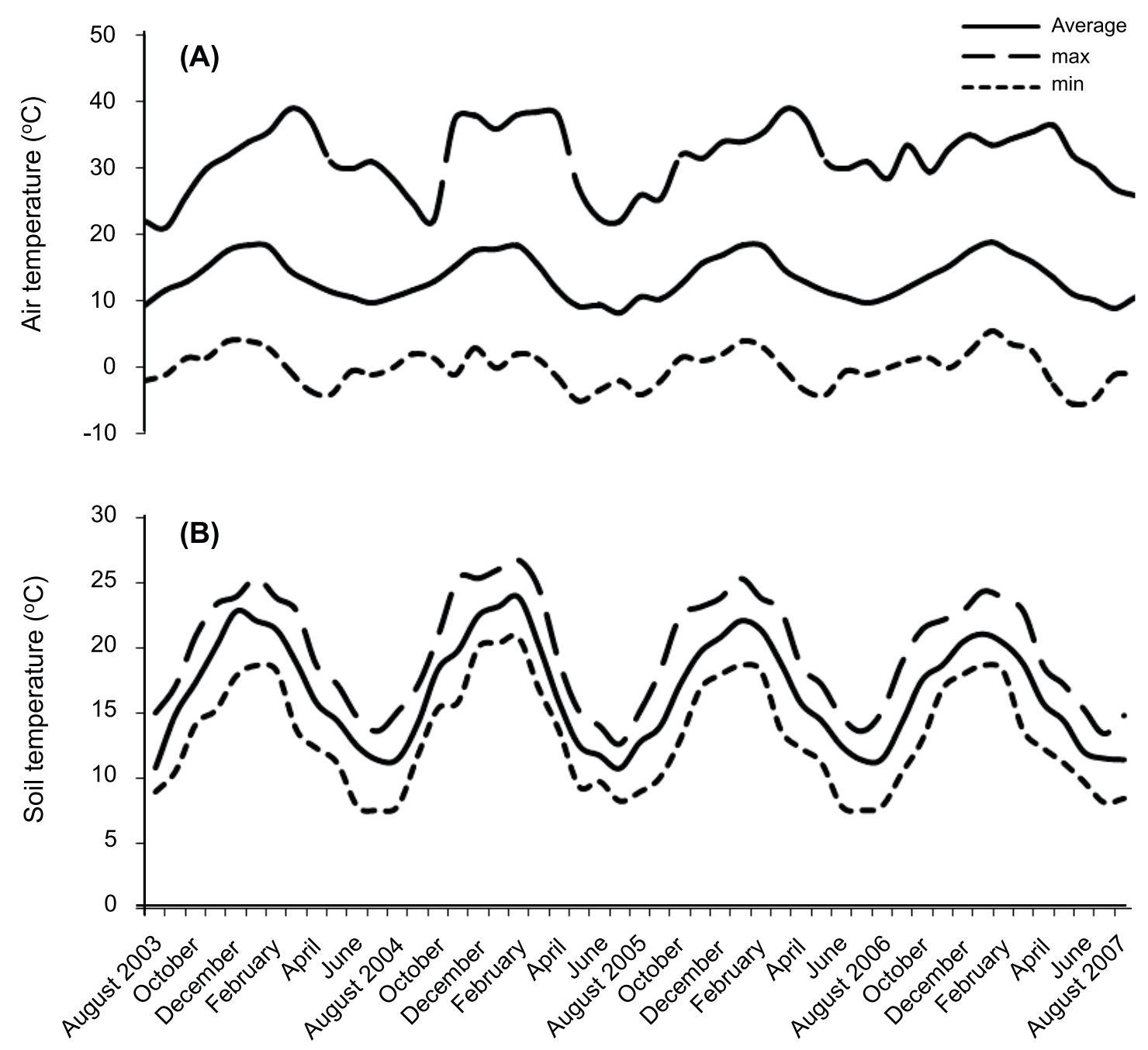

Figure 2 - Average, maximum and minimum air temperature (A) and at $15 \mathrm{~cm}$ of soil depth (B) from August 2003 to August 2007

and simazine adsorbed was calculated as the difference between the amount in the initial solution and the remaining in the solution after centrifugation. The sorption isotherm was determined according to the Langmuir model (Equation 1).

$$
C s=\frac{q m^{*} k^{*} C e}{1+k^{*} C e}
$$

where $C_{s}\left(\mathrm{mg} \mathrm{g}^{-1}\right)$ is the sorbed herbicide, $k$ is the equilibrium adsorption/desorption constant, $q m$ is maximum soil adsorption capacity, and $C_{e}\left(\mathrm{mg} \mathrm{mL}^{-1}\right)$ is the herbicide concentration in solution after $24 \mathrm{~h}$ of shaking.

After measurement of sorption the $3.5 \mathrm{~mL}$ remaining supernatant solution of each sample was replaced in the centrifuge tubes with the same volume of fresh background solution containing no herbicide. The new soil suspensions were shaken and centrifuged as described in the previous section. The whole desorption procedure was repeated twice, and the amount of diuron and simazine desorbed was calculated by determining its concentration in each of the three supernatant solutions.

\section{Statistical analysis}

Herbicide dissipation was fitted to Equation 2 (Hamaker, 1972), using non-linear regression analysis PROC NLIN (SAS $\left.{ }^{\circledR}\right)$, defined by: 


$$
\begin{aligned}
& C=\left[C o^{(1-n)}+(n-1) * k * t\right]^{1 /(1-n)} \\
& D T_{50}=1 / k * C_{o}
\end{aligned}
$$

where $C\left(\mathrm{mg} \mathrm{kg}^{-1}\right)$ is the soil herbicide concentration at time $t$ (day), $C_{o}$ is the initial soil concentration $\left(\mathrm{mg} \mathrm{kg}{ }^{-1}\right)$, and $k\left(\right.$ days $\left.^{-1}\right)$ is a second order $(n=2)$ rate constant that determines the slope of the curve. The goodness-of-fit of the model was calculated according to Schabenberger (2009). The $D T_{50}$ values were estimated from (Equation 3). The herbicide concentration in soil samples was analyzed using PROC UNIVARIATE (SAS $\left.{ }^{\circledR}\right)$. The effect of soil properties on soil adsorption and desorption was analyzed utilizing a PROC REG and stepwise selection model with $p=0.05$ for variable selection.

\section{RESULTS AND DISCUSSION}

$D T_{50}$ values for diuron differed according to rainfall conditions (Table 2). In all seasons, soil samples taken from irrigated plots showed a reduction in $D T_{50}$ values, which cannot be explained only by the soil moisture content during this period (Figure 3), but because twice more diuron was mobilized below $15 \mathrm{~cm}$ soil layer at 40 DAA under natural rainfall than irrigated in the three study seasons (data not shown). However, at 90 DAA diuron residues were the same under both rainfall conditions (Table 3).

Diuron soil residues, at the end of each study season, decreased each year from 2003 to 2007. After the first year of application, the residue represented $28 \%$ of the initial amount, after the second year $16-18 \%$, and after the third year $5-7 \%$ (Table 3), with no effect of rainfall conditions.

Simazine dissipation in soil was greater than diuron in all seasons, therefore showed smaller $D T_{50}$ in the $0-15 \mathrm{~cm}$ soil layer (Table 2; Figure 4 and 5). The higher $D T_{50}$ values for simazine were during 2003 under natural rainfall, year in which the less rain accumulation was registered during the first 90 DAA (39 mm; Figure 1). In the same year, under irrigation, the $D T_{50}$ value was similar to those obtained in 2004 and 2005. Diuron movement in soil was very similar during the 2004-2005 and 2005-2006 seasons. The exception was the 2003-2004 season, in which diuron was detected only in the first $30 \mathrm{~cm}$ soil

Table 2 - Half-lives $\left(D T_{50}\right)$ and second order dissipation rate $(k)$ during 2003, 2004, 2005 and 2006 years estimated according equation

\begin{tabular}{|c|c|c|c|c|c|c|c|}
\hline \multirow[b]{2}{*}{ Herbicide } & \multirow[b]{2}{*}{ Year } & \multicolumn{3}{|c|}{ Natural rainfall } & \multicolumn{3}{|c|}{ Irrigated } \\
\hline & & $\begin{array}{c}D T_{50} \\
\text { (days) }\end{array}$ & $\begin{array}{c}K \\
\left(\text { days }^{-1}\right)\end{array}$ & $\mathrm{R}^{2}$ & $\begin{array}{c}D T_{50} \\
\text { (days) }\end{array}$ & $\begin{array}{c}k \\
\left(\text { days }^{-1}\right)\end{array}$ & $\mathrm{R}^{2}$ \\
\hline \multirow{4}{*}{ Diuron } & 2003 & $\begin{array}{c}42.9 \\
( \pm 3.2)\end{array}$ & $\begin{array}{c}0.048 \\
( \pm 0.007)\end{array}$ & $0.89 * *$ & $\begin{array}{c}24.6 \\
( \pm 2.1)\end{array}$ & $\begin{array}{c}0.088 \\
( \pm 0.013)\end{array}$ & $0.89 * *$ \\
\hline & 2004 & $\begin{array}{c}35.8 \\
( \pm 4.0)\end{array}$ & $\begin{array}{c}0.054 \\
( \pm 0.011)\end{array}$ & $0.82 * *$ & $\begin{array}{c}25.8 \\
( \pm 2.6)\end{array}$ & $\begin{array}{c}0.075 \\
( \pm 0.014)\end{array}$ & $0.85 * *$ \\
\hline & 2005 & $\begin{array}{c}68.0 \\
( \pm 6.0) \\
\end{array}$ & $\begin{array}{c}0.021 \\
( \pm 0.003)\end{array}$ & $0.86 * *$ & $\begin{array}{c}56.9 \\
( \pm 4.7) \\
\end{array}$ & $\begin{array}{c}0.026 \\
( \pm 0.004)\end{array}$ & $0.88 * *$ \\
\hline & 2006 & $\begin{array}{c}69.2 \\
( \pm 4.8) \\
\end{array}$ & $\begin{array}{c}0.021 \\
( \pm 0.003)\end{array}$ & $0.89 * *$ & $\begin{array}{c}46.4 \\
( \pm 3.3)\end{array}$ & $\begin{array}{c}0.031 \\
( \pm 0.004)\end{array}$ & $0.90 * *$ \\
\hline \multirow{4}{*}{ Simazine } & 2003 & $\begin{array}{c}38.1 \\
( \pm 2.7) \\
\end{array}$ & $\begin{array}{c}0.039 \\
( \pm 0.005)\end{array}$ & $0.92 * *$ & $\begin{array}{c}16.9 \\
( \pm 1.1) \\
\end{array}$ & $\begin{array}{c}0.094 \\
( \pm 0.011)\end{array}$ & $0.94 * *$ \\
\hline & 2004 & $\begin{array}{c}14.5 \\
( \pm 1.3) \\
\end{array}$ & $\begin{array}{c}0.125 \\
( \pm 0.02) \\
\end{array}$ & $0.91 * *$ & $\begin{array}{c}7.5 \\
( \pm 0.7) \\
\end{array}$ & $\begin{array}{c}0.243 \\
( \pm 0.042)\end{array}$ & $0.94 * *$ \\
\hline & 2005 & $\begin{array}{c}13.5 \\
( \pm 0.9) \\
\end{array}$ & $\begin{array}{c}0.11 \\
( \pm 0.014) \\
\end{array}$ & $0.94 * *$ & $\begin{array}{c}12.8 \\
( \pm 1.0) \\
\end{array}$ & $\begin{array}{c}0.12 \\
( \pm 0.018) \\
\end{array}$ & $0.93 * *$ \\
\hline & 2006 & $\begin{array}{c}15.3 \\
( \pm 1.4)\end{array}$ & $\begin{array}{c}0.101 \\
( \pm 0.017)\end{array}$ & $0.90 * *$ & $\begin{array}{c}19.3 \\
( \pm 1.8)\end{array}$ & $\begin{array}{c}0.081 \\
( \pm 0.014)\end{array}$ & $0.90 * *$ \\
\hline
\end{tabular}
[2] for diuron and simazine $(0-15 \mathrm{~cm}$ soil depth) under two pluviometric conditions

Values between parentheses correspond to standard error. ${ }^{* *}$ Highly significant. 

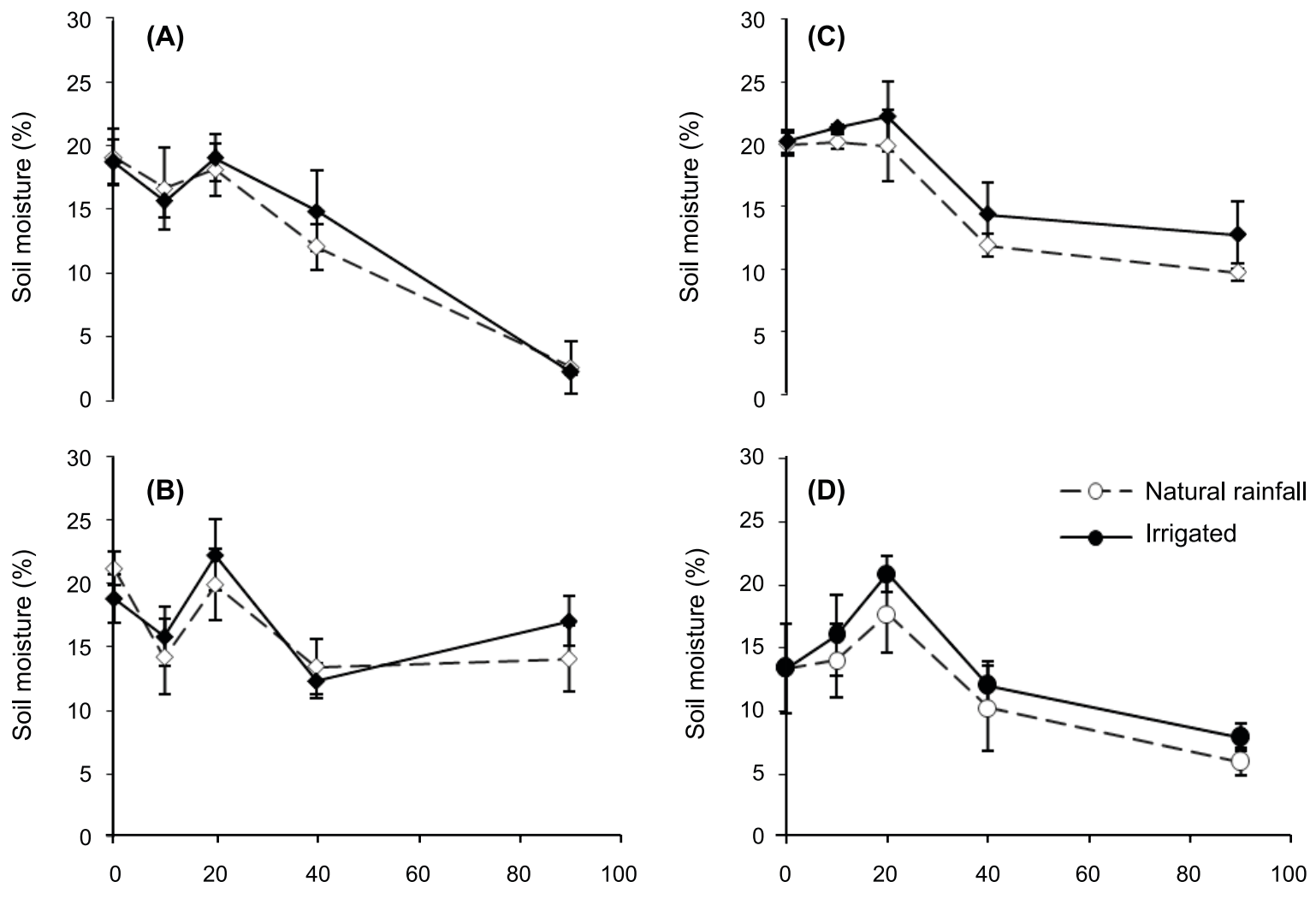

Days after herbicide application (DAA)

Days after herbicide application (DAA)

Figure 3 - Variation in soil moisture (\% of dry soil) between natural and modified conditions from 0 to $15 \mathrm{~cm}$ of soil layer. A) 2003 , B) 2004, C) 2005 and D) 2006. Error bars correspond to standard deviation.

Table 3 - Soil residues at 90 and 340 days after diuron and simazine applications under natural rainfall and irrigated conditions. Values correspond to herbicides recovery in the whole soil profile, expressed as percentage of the detected herbicide at the beginning of each season after herbicide application

\begin{tabular}{|c|c|c|c|c|c|}
\hline \multirow{2}{*}{$\begin{array}{c}\text { Herbicide application } \\
\text { year }\end{array}$} & \multirow{2}{*}{ Condition } & \multicolumn{2}{|c|}{ Diuron } & \multicolumn{2}{|c|}{ Simazine } \\
\hline & & 90 DAA & 340 DAA & $90 \mathrm{DAA}$ & 340 DAA \\
\hline \multirow{2}{*}{2003} & Natural rainfall & $\begin{array}{c}33.3 \\
( \pm 7.46)\end{array}$ & $\begin{array}{c}21.3 \\
( \pm 4.92)\end{array}$ & $\begin{array}{c}29.7 \\
( \pm 7.14)\end{array}$ & $\begin{array}{c}20.2 \\
( \pm 8.57)\end{array}$ \\
\hline & Irrigated & $\begin{array}{c}26.7 \\
( \pm 8.08) \\
\end{array}$ & $\begin{array}{r}18.3 \\
( \pm 5.23) \\
\end{array}$ & $\begin{array}{c}23.1 \\
( \pm 6.95) \\
\end{array}$ & $\begin{array}{c}12.0 \\
( \pm 3.63) \\
\end{array}$ \\
\hline \multirow{2}{*}{2004} & Natural rainfall & $\begin{array}{c}44.6 \\
( \pm 7.14)\end{array}$ & $\begin{array}{c}21.1 \\
( \pm 8.30)\end{array}$ & $\begin{array}{c}41.3 \\
( \pm 4.32)\end{array}$ & $\begin{array}{c}6.5 \\
( \pm 1.58)\end{array}$ \\
\hline & Irrigated & $\begin{array}{c}37.2 \\
( \pm 9.80)\end{array}$ & $\begin{array}{c}17.6 \\
( \pm 1.57) \\
\end{array}$ & $\begin{array}{c}25.7 \\
( \pm 10.0)\end{array}$ & $\begin{array}{c}7.0 \\
( \pm 0.52)\end{array}$ \\
\hline \multirow{2}{*}{2005} & Natural rainfall & $\begin{array}{c}42.3 \\
( \pm 14.9) \\
\end{array}$ & $\begin{array}{r}12.8 \\
( \pm 3.74) \\
\end{array}$ & $\begin{array}{c}17.1 \\
( \pm 7.21) \\
\end{array}$ & $\begin{array}{c}11.2 \\
( \pm 1.67) \\
\end{array}$ \\
\hline & Irrigated & $\begin{array}{c}36.6 \\
( \pm 7.36) \\
\end{array}$ & $\begin{array}{c}14.9 \\
( \pm 0.76) \\
\end{array}$ & $\begin{array}{c}15.7 \\
( \pm 4.49) \\
\end{array}$ & $15.5( \pm 5.05)$ \\
\hline \multirow{2}{*}{2006} & Natural rainfall & $\begin{array}{c}56.6 \\
( \pm 11.11)\end{array}$ & $\begin{array}{c}9.8 \\
( \pm 2.08)\end{array}$ & $\begin{array}{c}16.9 \\
( \pm 11.94)\end{array}$ & $\begin{array}{c}3.3 \\
( \pm 1.54)\end{array}$ \\
\hline & Irrigated & $\begin{array}{c}44.5 \\
( \pm 1.53)\end{array}$ & $\begin{array}{c}13.3 \\
( \pm 6.56)\end{array}$ & $\begin{array}{c}3.7 \\
( \pm 1.2)\end{array}$ & $\begin{array}{c}9.3 \\
( \pm 5.67) \\
\end{array}$ \\
\hline
\end{tabular}

Values in parentheses correspond to standard deviations. 
depth (Figure 4). This limited movement could be explained considering that this herbicide was applied for the first time in this soil in August 2003, and it is possible that diuron was leached below $30 \mathrm{~cm}$ deep through soil pore water, but at a very low concentration, which could not be detected (Guzzella et al., 2006). On the other seasons, diuron moved down up to $90 \mathrm{~cm}$, regardless of the rainfall that occurred during the first 90 DAA (2003-39 mm; 2004-78 mm; 2005-165 mm; 2006-87 mm (Figure 2).

In contrast, simazine showed always a deeper movement in soil (Figure 5) and, as occurred for diuron, its downward movement in soil was affected by the rainfall amount occurred in the first 90 DAA.

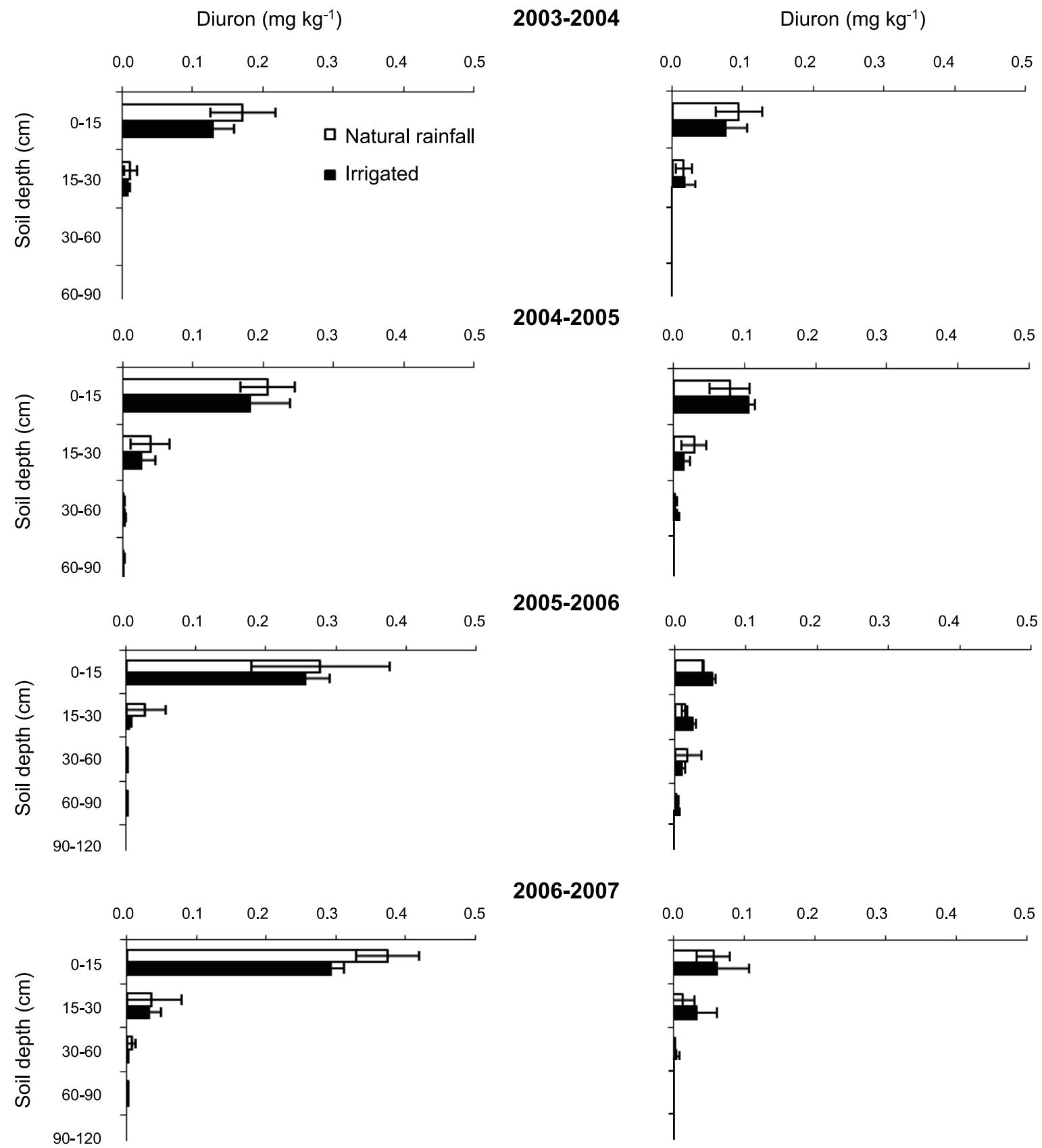

Figure 4 - Diuron soil concentration $\left(\mathrm{mg} \mathrm{kg}^{-1}\right)$ in the soil profile at 90 (Left) and 340 (Right) days after application, in both conditions during seasons 2003-2004, 2004-2005, 2005-2006 and 2006-2007. Error bars correspond to the standard deviations. 


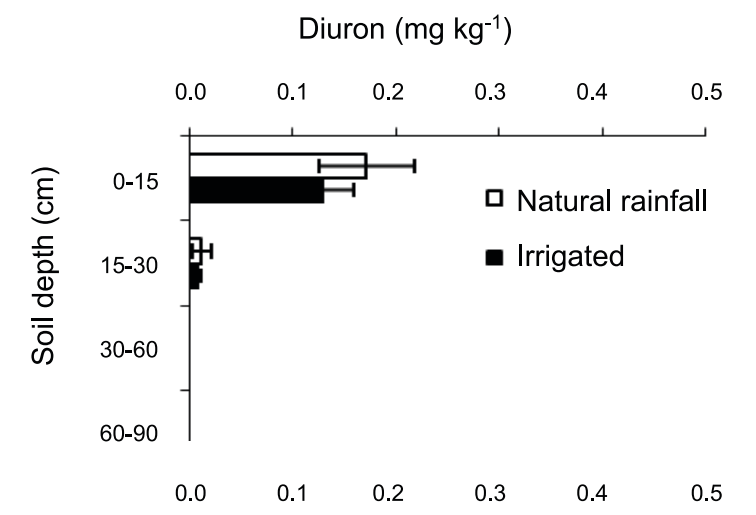

2003-2004
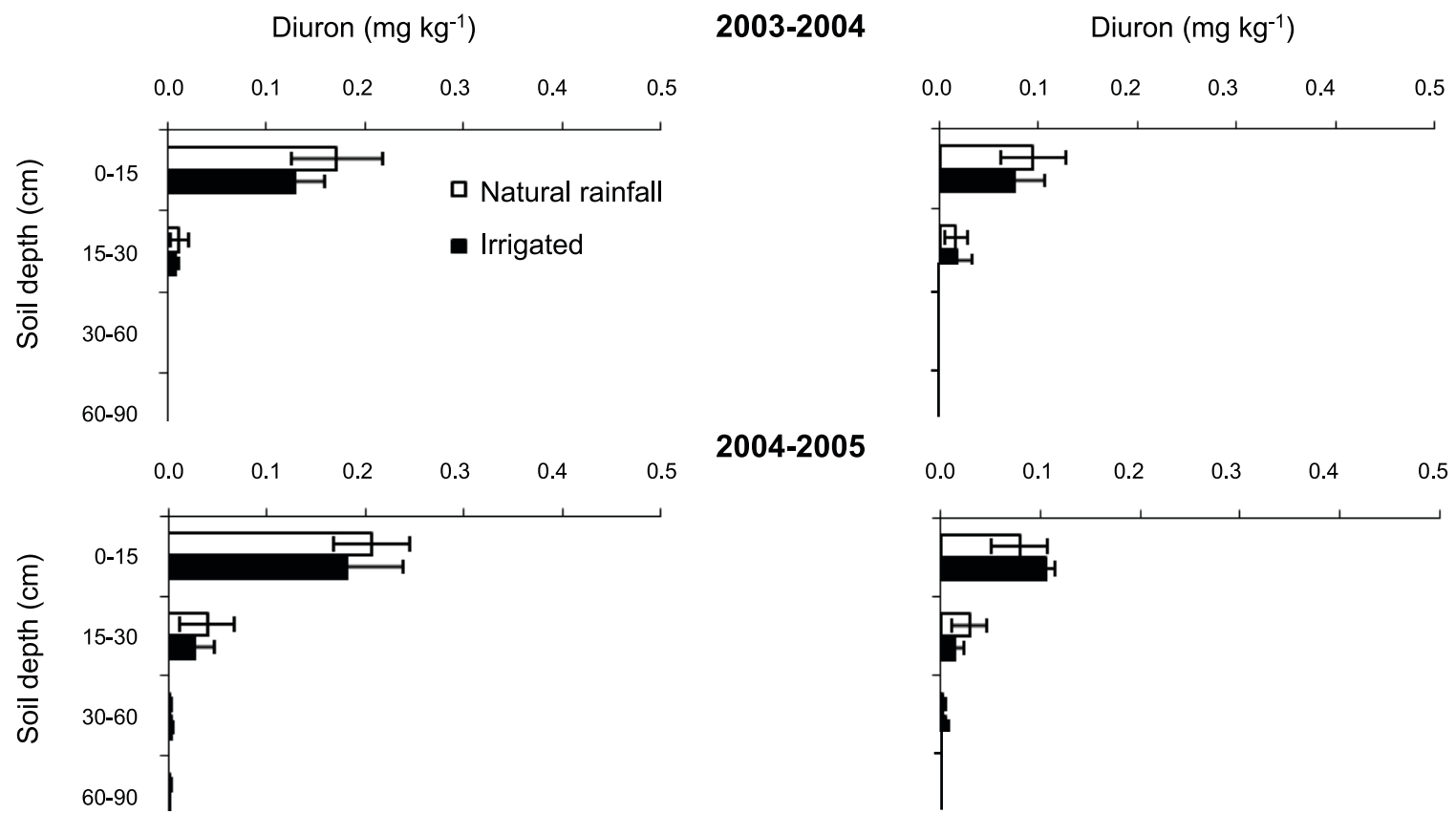

2004-2005
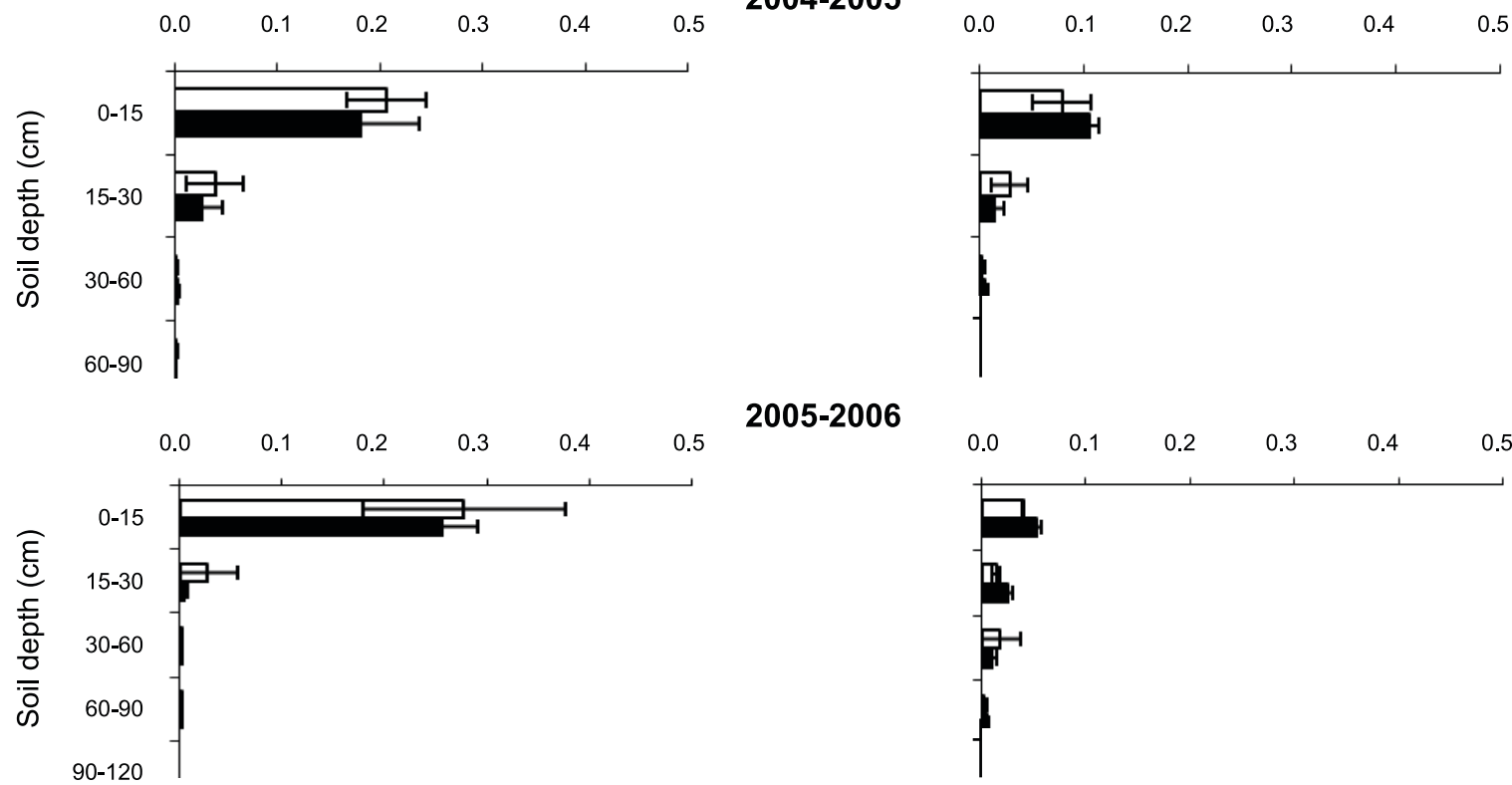

2005-2006
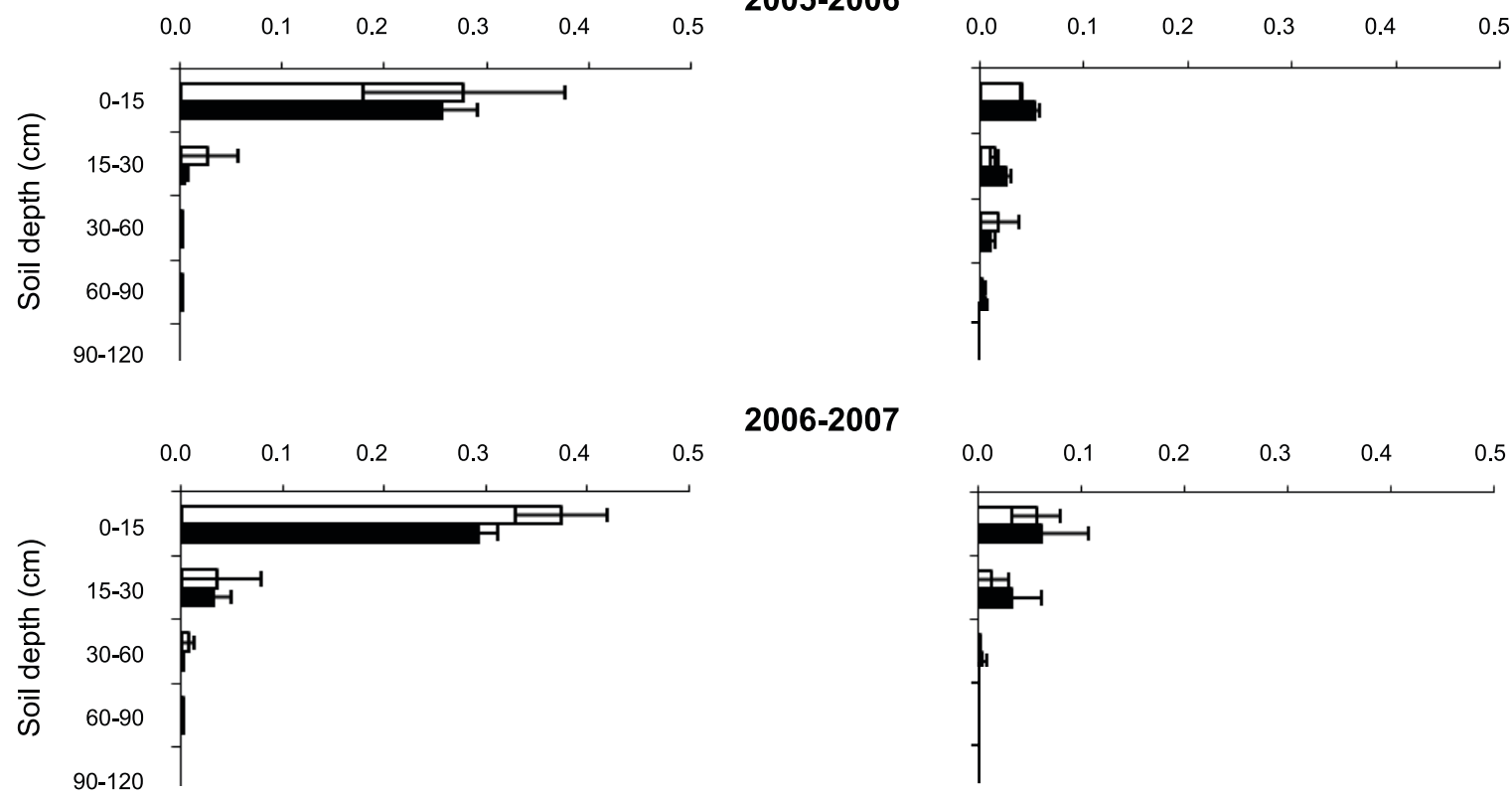

2006-2007

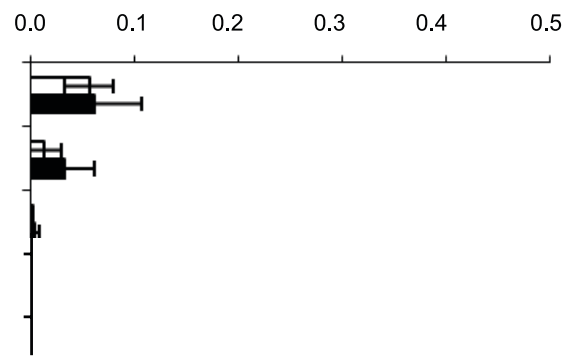

Figure 5 - Simazine soil concentration $\left(\mathrm{mg} \mathrm{kg}^{-1}\right)$ in the soil profile at 90 (Left) and 340 (Right) days after application, in both conditions during seasons 2003-2004, 2004-2005, 2005-2006 and 2006-2007. Error bars correspond to the standard deviations.

The main difference between diuron and simazine, regardless of their downward movement, was the amount of herbicide distributed in the soil profile. In the three seasons, and independent of the rainfall conditions, more than $60 \%$ of simazine was detected at 90 DAA below $15 \mathrm{~cm}$. Only during 2003 and under natural rainfall, simazine found below $15 \mathrm{~cm}$ soil depth represented only
$17 \%$. However, more than $65 \%$ of simazine was found in this soil layer at 340 DAA. Considering that the residues found were similar in both conditions at 340 DAA in the 2004 season (Table 3 and 4), the change in simazine soil distribution could be due to an increase in herbicide mass mobilized below $15 \mathrm{~cm}$ deep as a response to the $323 \mathrm{~mm}$ of rain that occurred from November 2003 to August 2004. 
Ninety days after application, the amount of diuron detected below $15 \mathrm{~cm}$ was $4.9 \%$, $15.4 \%, 7.6 \%$ and $8.8 \%$ under natural rainfall and $5.9 \%, 13.7 \%, 2.3 \%$ and $10.3 \%$ for irrigated plots during the 2003-2004, 2004-2005, 20052006 and 2006-2007 seasons, respectively; therefore the effect of the amount of rainfall during the first 90 DAA was not important. However, 250 days later (340 DAA), diuron distribution in the soil profile changed to $15.8 \%, 29.8 \%, 53.1 \%$ and $24.2 \%$ for the irrigated plots, and $20.0 \%, 18.0 \%, 51.1 \%$ and $38.8 \%$, for the plots that received the natural rainfall, during 2003-2004, 2004-2005, 20052006 and 2006-2007, respectively. The increased amount of diuron detected below $15 \mathrm{~cm}$ soil depth could be explained because rainfall after 90 DAA (Figure 1) could move diuron to deeper soil layers (Figure 4).

The adsorption for diuron and simazine decreased with soil depth, and the desorption increased (Table 4). Diuron $K_{d}$ was greater in the topsoil $(0-15 \mathrm{~cm})$ and was $60 \%$ less at $60-$ $90 \mathrm{~cm}$ deep ; however, desorption was around $120 \%$ greater at $60-90 \mathrm{~cm}$ of soil depth. In contrast, simazine $K_{\mathrm{d}}$ was only $41 \%$ at $60-$ $90 \mathrm{~cm}$ of soil depth, and the increase in simazine desorption was also low at 33\%.

Changes in the sorption-desorption process down the soil profile could be related to the decrease in organic carbon content in the deeper soil layer, but this effect was herbicide dependent. Thus, a stepwise selection model for $K_{d}$ showed that organic carbon content explained $81 \%(\mathrm{p}<0.0001)$ of diuron sorption but only $61 \%(p=0.0003)$ for simazine. On the other hand, soil carbon content explained $76 \%$ of diuron desorption, with $37.1 \%$ of desorption percentage increase for each $1 \%$ unit of organic carbon decrease. However, simazine desorption showed only $18.7 \%$ increase on desorption percentage for each $1 \%$ unit of organic carbon reduction, explaining $84 \%$ of the desorption process $(p<0.0001)$. This indicates that soil organic carbon content, in this soil, was less important for simazine than for diuron sorption.

The dissipation of diuron increased over the years, after repeated applications. This is not evident if the $D T_{50}$ values are compared (Table 2), but it is clear if diuron residues remaining at 340 DAA in every year are compared (Table 3 ). This could be mainly due to the combination of two factors. Firstly, this is probably due to a higher degradation rate, by adaptation of a microorganism population that degraded the herbicide ("soil enrichment"). This phenomenon has been reported for phenylurea herbicides used repeatedly for 3 to 12 years (Walker \& Welch, 1991; Rouchard et al., 2000). Second, the increase in rainfall during August to April of each season, (Figure 2) was accompanied by the increase in soil temperature from November each year (over $19^{\circ} \mathrm{C}$, Figure 1 ). This would provide adequate soil moisture and temperature in the $0-15 \mathrm{~cm}$ soil layer for microbiological degradation of diuron (Baer \& Calvet, 1999).

Diuron soil residues at 90 DAA and at the end of each season (Table 3) do not mean soil accumulation (Sheets, 1964; Rouchard et al., 2000). Moreover, the inconsistencies observed

Table 4 - Diuron and simazine sorption coefficients and herbicide desorption (\%) after three desorption steps

\begin{tabular}{|c|c|c|c|c|c|c|}
\hline \multirow{3}{*}{$\begin{array}{l}\text { Soil depth } \\
\text { (cm) }\end{array}$} & \multicolumn{3}{|c|}{ Diuron } & \multicolumn{3}{|c|}{ Simazine } \\
\hline & $K_{\mathrm{d}}$ & $K_{\mathrm{oc}}^{\mathrm{a}}$ & Desorption & $\overline{K_{\mathrm{d}}}$ & $K_{\mathrm{oc}}^{\mathrm{a}}$ & Desorption \\
\hline & \multicolumn{2}{|c|}{$\left(\mathrm{mL} \mathrm{g}^{-1}\right)$} & $(\%)$ & \multicolumn{2}{|c|}{$\left(\mathrm{mL} \mathrm{g}^{-1}\right)$} & $(\%)$ \\
\hline $0-15$ & $\begin{array}{c}6.75 \\
( \pm 0.37)\end{array}$ & $\begin{array}{c}528 \\
( \pm 28)\end{array}$ & $\begin{array}{c}29 \\
( \pm 2)\end{array}$ & $\begin{array}{c}1.40 \\
( \pm 0.16)\end{array}$ & $\begin{array}{c}109 \\
( \pm 13)\end{array}$ & $\begin{array}{c}54 \\
( \pm 2)\end{array}$ \\
\hline $15-30$ & $\begin{array}{c}3.76 \\
( \pm 0.12)\end{array}$ & $\begin{array}{c}596 \\
( \pm 19)\end{array}$ & $\begin{array}{c}54 \\
( \pm 0.6)\end{array}$ & $\begin{array}{c}0.91 \\
( \pm 0.02)\end{array}$ & $\begin{array}{l}145 \\
( \pm 3)\end{array}$ & $\begin{array}{c}71 \\
( \pm 0.7)\end{array}$ \\
\hline $30-60$ & $\begin{array}{c}2.04 \\
( \pm 0.03)\end{array}$ & $\begin{array}{l}409 \\
( \pm 6) \\
\end{array}$ & $\begin{array}{c}73 \\
( \pm 0.5) \\
\end{array}$ & $\begin{array}{c}0.66 \\
( \pm 0.01)\end{array}$ & $\begin{array}{l}133 \\
( \pm 1) \\
\end{array}$ & $\begin{array}{c}73 \\
( \pm 1) \\
\end{array}$ \\
\hline $60-90$ & $\begin{array}{c}2.29 \\
( \pm 0.07)\end{array}$ & $\begin{array}{r}737 \\
( \pm 21) \\
\end{array}$ & $\begin{array}{c}66 \\
( \pm 1.8) \\
\end{array}$ & $\begin{array}{c}0.89 \\
( \pm 0.01)\end{array}$ & $\begin{array}{l}286 \\
( \pm 3) \\
\end{array}$ & $\begin{array}{c}72 \\
( \pm 0.2) \\
\end{array}$ \\
\hline
\end{tabular}

Values are means of four replicates \pm standard error. ${ }^{1 /} \mathrm{Koc}=K_{d} / f_{o c}$. 
between increases in $D T_{50}$ values over the years (Table 2) and the soil residues at 90 DAA agreed with the earlier observations over one year of simazine behaviour in soil (Alister et al., 2005), which indicated that $D T_{50}$ alone is not a good parameter to compare the persistence of compounds under field conditions.

In contrast to diuron, simazine was not degraded more rapidly despite the experimental area in the vineyard had received simazine since 1998 at the same rate $\left(2 \mathrm{~kg} \mathrm{ha}^{-1}\right.$ a.i.). This maybe is due to a particular characteristic of the simazine molecule, which does not induce soil conditioning or soil enrichment (Rouchaud et al., 2000; Walker \& Welch, 1991).

From simazine $D T_{50}$ values for the first year of application in the case of natural rainfall (Alister et al., 2005), considering the whole soil profile $(0-90 \mathrm{~cm})$, this herbicide showed only a slight difference for the $D T_{50}$ determined in the $0-15 \mathrm{~cm}$ soil layer. However, in irrigated plots $D T_{50}$ values from the whole soil profile $(0-90 \mathrm{~cm})$ and at $0-15 \mathrm{~cm}$ soil layer were the same, indicating that the herbicide degradation was not reduced with soil depth (Di et al., 1998; Sparling et al., 1998; Karpouzas et al., 2001). This is supported by the low $K_{d}$ and high desorption percentage determined in the soil profile (Table 4). This allowed a large amount of simazine to be available for microbiological degradation. Also, soil moisture and temperature at $60 \mathrm{~cm}$ deep were the same as in the $0-15 \mathrm{~cm}$ soil layer (data not shown) and the $O C$ content in the $30-60$ soil depth layer were over $0.5 \%$, a value considered not critical with respect to microbiological activity (Tariq et al., 2006).

Diuron downward movement was limited to $30 \mathrm{~cm}$ deep during the 2003 season. However, it reached up to $90 \mathrm{~cm}$ deep in the next two seasons (2004 and 2005). These results do not agree with other research, which showed that diuron was not leached more than $50 \mathrm{~cm}$ in the soil (Majka \& Lavy, 1977; Barreda et al., 1996; Futch \& Singh, 1999; Tworkoski et al., 2000; Sharma \& Singh, 2001; Guzzella et al., 2006).

As diuron and simazine leaching in soil was not affected by rainfall conditions (natural or irrigated). However, the rapid downward movement, to 90 and $120 \mathrm{~cm}$ for diuron and simazine respectively, during the first 90 DAA could be a confirmation of the preferential flow pathways as suspected in 2003 by Alister et al. (2005). This can be corroborated if the amount of water needed to displace herbicides in soil profile is calculated according to the equation for piston flow (Isensee et al., 1990):

$$
\begin{aligned}
& I=D^{*} \theta_{F C} * R \\
& R=1+\left(\frac{\rho^{*} K d}{\theta_{F C}}\right)
\end{aligned}
$$

where, $I$ is the water amount needed to move an herbicide to a certain soil depth $(\mathrm{cm}) ; D$ is the distance traveled by the herbicide $(\mathrm{cm}) ; \theta_{F C}$ is the water content at field capacity $\left(\mathrm{cm}^{3} \mathrm{~cm}^{-3}\right)$; $R$ is the retention factor; $\rho$ is the bulk density ( $\mathrm{g} \mathrm{mL}^{-1}$ ); and $K_{d}$ is the herbicide soil partition coefficient $\left(\mathrm{mL} \mathrm{g}^{-1}\right)$. Using the measured parameters for diuron and simazine, soil properties (Table 1) and soil water content (Figure 3), 505.7 and $195.9 \mathrm{~cm}$ of rainfall would be needed during the first 90 DAA to mobilize diuron and simazine to 90 and $120 \mathrm{~cm}$ deep, respectively. Apart from the preferential flow, the low sorption energy of these herbicides (low $K_{\mathrm{d}}$ and high desorption percentage) (Table 4) (Jury et al., 1987; ARS, 2001; Oliveira et al., 2001) would result in non-equilibrium sorption (Pignatello \& Huang, 1991; Kookana et al., 1992), which could also explain the depth reached and mass amount of diuron and simazine moved in the soil under field condition on four years of the study.

Organic carbon content was very important for diuron sorption in determining the soil partitioning process, and this is in concordance with previous reports (Bollag \& Meyers, 1992; Bollag et al., 1992; Senesi, 1992). Even though, for simazine OC content was not the only factor responsible for soil sorption-desorption process, contrary to what has been previously reported (Sullivan \& Felbeck, 1968; Senesi \& Testini, 1980; Gevao et al., 2000). In this specific soil, other mechanisms such as reaction with clay surfaces could have occurred (Sukop \& Cogger, 1992; Inoue et al., 2004), and probably there would be a negative effect of organic substances 
on simazine sorption, which could act as a barrier, avoiding the ability of clay, mainly caolinite in this case, to adsorb simazine (Zsolnay et al., 2002).

In general, we can expect a direct relationship between rainfall and the dissipation rate during the first 90 DAA, but the overall year dissipation process should not be affected by rainfall because similar soil residues occur at the end of each season (350 DDA). This could be explained by the deep movement of the herbicide in the soil during that time, which enhances the dissipation at this soil layer, more over the soil degradation. Thus the use of $D T_{50}$ as the only indicator of herbicide persistence in soil is not totally adequate. However, diuron showed a "soil conditioning" effect after four years of repeated applications, whereas simazine did not.

The soil depth reached by diuron $(90 \mathrm{~cm})$ and simazine $(120 \mathrm{~cm})$, and the mass leached below $15 \mathrm{~cm}$ was not affected by the rainfall during the seasons and the additional rainfall applied during the first 90 DAA. The downward movement of both herbicides in this soil was a result of preferential flow, low $K_{d}$ values and high desorption percentage.

\section{ACKNOWLEDGEMENTS}

The authors wish to thank FONDECYT (Chilean Fund for Science and Technology) for funding the Project Number 1030990 and to CONICYT (Chilean Commission of Scientific Research and Technology) for the doctorate scholarship to C. Alister.

\section{LITERATURE CITED}

ALISTER, C.; LÓPEZ, R.; KOGAN, M. Simazine dynamics in a vineyard soil at Casablanca valley, Chile. Pest Manag. Sci., v. 61, n. 11, p. 1083-1088, 2005.

ALISTER, C.; KOGAN, M. ERI: Environmental risk index. A simple proposal to select agrochemicals for agricultural use.

Crop Protec., v. 25, n. 3, p. 202-211, 2005.

ARS, 2001. Pesticide Properties Database. Disponível em: $<$ http://www.arsusda.gov/acsl/listall.htmL. $>$. Acesso em: 12 mar. 2010

BAER, U.; CALVET, R. Fate of soil applied herbicides: experimental data and prediction of dissipation kinetics. J. Environ. Quality, v. 28, n. 6, p. 1765-1777, 1999.
BARREDA, D. et al. Persistence and leaching of some residual herbicides in uncropped soils. B. Environ. Contam. Toxicol., v. 56, n. 2, p. 219-224, 1996.

BOLLAG, J.; MYERS, C. Detoxification of aquatic and terrestrial sites through binding of pollutants to humic substances. Sci. Total Environ., v. 117/118, p. 357-366, 1992.

BOLLAG, J.; MYERS, C.; MINARD, R. Biological and chemical interactions of pesticides with soils. Sci. Total Environ., v. 123/124, p. 205-217, 1992.

DAWSON, J.; BRUNS, V.; CLORE, W. Residual monuron, diuron, and simazine in vineyard soil. Weed Sci., v. 16, p. $63-65,1968$

DI, H.; AYLMORE, L.; KOOKANA, R. Degradation rates of eight pesticides in surface and subsurface soils under laboratory and field conditions. Soil Sci., v. 163, p. 404-411, 1998.

FIELD, J. et al. Diuron occurrence and distribution in soil and surface and ground water associated with grass seed production. J. Environ. Quality, v. 32, n. 1, p. 171-179, 2003.

FLURY, M. Experimental evidence of transport of pesticides through field soil - a review. J. Environ. Quality, v. 25, n. 1, p. $25-45,1996$

FUTCH, S.; SINGH, M. Herbicide mobility using soil leaching columns. B. Environ. Contam. Toxicol., v. 62, n. 5, p. 520-529, 1999.

GEVAO, B.; SEMPLE, K.; JONES, K. Bound pesticides residues in soils: a review. Environ. Pollution, v. 108, n. 1, p. 3-14, 2000.

GOODDY, D.; CHILTON, J.; HARRISON, I. A field study to assess the degradation and transport of diuron and its metabolites in a calcareous soil. Sci. Total Environ., v. 297, n. 1, p. 67-83, 2002.

GUSTAFSON, D. Groundwater ubiquity score: a simple method for assessing pesticide leachability. Environ. Toxicol. Chem., v. 8, n. 4, p. 339-357, 1989.

GUZZELLA, L. et al. Fate of diuron and linuron in a field lysimeter experiment. J. Environ. Quality, v. 35, n. 1, p. 312-323, 2006.

HAMAKER, J. Decomposition: quantitative aspects. In: GORING, C.; HAMAKER, J., (Eds.). Organic chemicals in the soil environment. New York: Dekker, 1972. p. 253-340.

HEENEY, H.; WARREN, V.; KHAN, S. Effects of annual repeat applications of simazine, diuron, terbacil, and dichlobenil in a mature apple orchard. Canadian J. Plant Sci., v. 61, p. 325-329, 1981 
ISENSEE, A.; NASH, R.; HELLING, C. Effect of conventional vs. no-tillage on pesticide leaching to shallow groundwater. J. Environ. Quality, v. 19, p. 434-440, 1990.

ITOH, M.; MANABE, K. Effect of leaching of a soil applied herbicide, diuron, on its phytotoxicity in grape and peach. J. Japanese Soc. Hortic. Sci., v. 66, n. 2, p. 221-228, 1997.

INOUE, M. et al. Sorption kinetics of atrazine and diuron in soils from southern Brazil. J. Environ. Sci. Health. Part B, v. 39 , n. 4 , p. $589-601,2004$.

JACOBSEN, S. et al. Transport and dating of pesticide residues from a 40 years old point source. In: Proceedings of the XI Symposium Pesticide Chemestry. DEL RE, A. A. M. et al. (Eds.). La goliardica pavese. Pavid, Italy: 1999. p. $355-362$.

JURY, W.; FOCHT, D.; FARMER, W. Evaluation of pesticide groundwater pollution potential from standard indices of soilchemical sorption and biodegradation. J. Environ. Quality, v. 16, n. 4 , p. $422-428,1987$.

KARPOUZAS, D. et al. The effect of initial concentration of carbofuran on the development and stability of its enhanced biodegradation in top-soil and sub-soil. Pest Manag. Sci., v. 57, n. 1, p. $72-81,2001$.

LANDRY, D.; DOUSSET, S.; ANDREUX, F. Leaching of oryzalin and diuron through undisturbed vineyard soil columns under outdoor conditions. Chemosphere, v. 62, p. $1736-1747,2006$

LASKOWSKI, D. et al. Terrestrial environment. In: CONWAY, R.A. (Ed.). Environmental risk analysis for chemicals New York: Van Nostrand Reinhold Co., 1982. p. 198-240.

KOOKANA, R.; AYLMORE, A.; GERRITSE, R. Timedependent sorption of pesticide during transport in soils. Soil Sci., v. 154, n. 3, p. 214-225, 1992.

LENNARTZ, B. et al. Diuron and simazine losses to runoff water in Mediterranean vineyards. J. Environ. Quality, v. 26, p. 1493-1502, 1997.

LIYANAGE, J. et al. Sorption of carbofuran and diuron pesticides in 43 tropical soils of Sri Lanka. J. Agric. Food Chem., v. 54, p. 1784-1791, 2006.

NATIONAL WATER-QUALITY ASSESSMENT PROGRAM - NAWQA. Summary Statistic; preliminary results from cycle I of the National Water Quality Assessment Program, 1992-2001. Disponível em: <http:// ca.water.usgs.gov/pnsp/pestgw/Pest-GW_2001_text.htmL> Acesso:12 mar. 2010.

MAJKA, J.; LAVY, T. Sorption, mobility, and degradation of cyanazine and diuron in soils. Weed Sci., v. 25, p. 401-406, 1977.
MATALLO, M. B. et al. Sorption, degradation, and leaching of tebuthiuron and diuron in soil columns. J. Environ. Sci. Health: Part B, v. 40, p. 39-43, 2005.

MEEKS Y; DEAN J. Evaluating groundwater vulnerability to pesticides. J. Water Res. Planning Manag., v. 116, p. 693-707, 1990.

OLIVEIRA, R.; KOSKINEN, W.; FERREIRA, F. Sorption and leaching of herbicides on Brazilian soils. Weed Res., v. 41, p. 97-110, 2001.

PATZOLD, S.; BRUMMER, G. Fate, sorption, and leaching of the herbicide diuron after annual application in a orchard soil (Orthic Luvisol). Original title: Abbau, Sorptions und Verlagerungsverhalten des Herbizides Diuron in einer obstbaulich genutzten Parabraunerde aus loss. Zeitschrift Pflanzenernahrung und Bodenk., v. 160, n. 2, p. 165-170, 1997.

PIGNATELLO, J.; HUANG, L. Sorptive reversibility of atrazine and metolachlor residues in field soil samples. J. Environ. Quality, v. 20, p. 222-228, 1991.

ROUCHAUD, J. et al. Soil dissipation of diuron, chlorotoluron, simazine, propyzamide, and diflufenican herbicides after repeated applications in fruit tree orchards. Arch. Environ. Contam. Toxicol., v. 39, n. 1, p. 60-65, 2000

SENESI, N. Binding mechanisms of pesticides to soil humic substances. Sci. Total Environ., v. 123/124, p. 63-76, 1992

SENESI, N.; TESTINI, C. Sorption of some nitrogenated herbicides by soil humic acids. Soil Sci., v. 10, p. 314-320, 1980 .

SHARMA, S.; SINGH, M. Susceptibility of Florida candler fine soil to herbicide leaching. B. Environ. Contam. Toxicol. v. 67 , p. $594-600,2001$

SHEETS, T. Review of disappearance of substituted urea herbicides from soils. J. Agric. Food Chem., v. 12, p. 30-33, 1964.

SPARLING, G. et al. Atrazine mineralisation in New Zealand topsoils and subsoils: influence of edaphic factors and number of atrazine-degrading microbes. Austr. J. Soil Res., v. 36, p. 557-570, 1998.

SPALDING, R. et al. Herbicides in groundwater beneath Nebraska's management systems evaluation area. J. Environ. Quality, v. 32, n. 1, p. 92-99, 2003.

SCHABENBERGER, O. Nonlinear regression in SAS. [WWW document]. URL: Disponível em: <http:// home.nc.rr.com/schabenb/.>. Acesso em: 12 de out. 2009. 
SUKOP, P.; COGGER, C. Sorption of carbofuran, metalaxil, and simazine : Koc evaluation and relation to soil transport.

J. Environ. Sci. Health: Part B, v. 27, n. 5, p. 565-590, 1992.

SULLIVAN, J.; FELBECK, G. A study of the interaction of s-triazine herbicide with humic acids from three different soils. Soil Sci., v. 106, n. 1, p. 42-52, 1968

TARIQ, M.; AFZALB, S.; HUSSAINC, I. Degradation and persistence of cotton pesticides in sandy loam soils from Punjab, Pakistan. Environ. Res., v. 100, p. 184-196, 2006

TROIANO, J. et al. Use of cluster and principal component analyses to profile areas in California where groundwater has been contaminated by pesticides. Environ. Monitoring Assessing, v. 32, p. 269-288, 1994.

TWORKOSKI, T.; WELEKER, W.; VASS, G. Soil residues following repeat applications of diuron, simazine, and terbacil. Weed Technol., v. 14, p. 191-196, 2000.
WADE, H. et al. The impact of pesticide use on groundwater in North Carolina. J. Environ. Quality, v. 27, p. 1018-1026, 1998.

WAUCHOPE, R. et al. The SCS/ARS/CES pesticide properties database for environmental decision making. Rev. Environ. Contam. Toxicol., v. 23, p. 1-157, 1992.

WALKER, A.; WELCH, S. Enhanced degradation of some soil applied herbicides. Weed Res., v. 31, n. 1, p. 49-57, 1991.

ZSOLNAY,A. et al. The effect of soil mineral-organic matter interaction on simazine sorption and desorption. In: Violant, A. et al. (Eds.). Soil mineral-organic mattermicroorganism interactions and ecosystem health. Dynamics, mobility ans transformation of pollutants and nutrients. Development in Soil Science, v. 28A, 2002 p. $137-142$ 